Revista Española de Derecho Internacional Sección PRÁCTICA ESPAÑOLA DE DERECHO INTERNACIONAL

Vol. 70/1, enero-junio 2018, Madrid, pp. 295-298 http://dx.doi.org/10.17103/redi.70.1.2018.3.03 (C) 2018 Asociación de Profesores de Derecho Internacional y Relaciones Internacionales ISSN: 0034-9380; E-ISSN: 2387-1253

\title{
DECLARACIÓN SOBRE LA FALTA DE FUNDAMENTACIÓN EN EL DERECHO INTERNACIONAL DEL REFERÉNDUM DE INDEPENDENCIA EN CATALUÑNA ${ }^{1}$
}

\author{
Ante los errores en la invocación del Derecho internacional para dotar \\ de fundamento jurídico a la ley del referéndum de autodeterminación, los \\ miembros de la Asociación Española de Profesores de Derecho Internacional \\ y Relaciones Internacionales (AEPDIRI) abajo firmantes consideran que es \\ su obligación cívica formular la siguiente declaración:
}

\footnotetext{
1 Los Profesores Paz Andrés Sáenz de Santa María (Universidad de Oviedo), Gregorio Garzón Clariana (Universidad Autónoma de Barcelona), Araceli Mangas Martín (Universidad Complutense de Madrid), Xavier Pons Rafols (Universidad de Barcelona), Antonio Remiro Brotóns (Universidad Autónoma de Madrid), Alejandro del Valle Gálvez (Universidad de Cádiz) y Rafael Arenas García (Universidad Autónoma de Barcelona), miembros de la Asociación Española de Profesores de Derecho Internacional y Relaciones Internacionales (AEPDIRI), elaboraron el 19 de septiembre de 2017 esta «Declaración sobre la falta de fundamentación en el Derecho internacional del referéndum de independencia que se pretende celebrar en Cataluña», que quedó abierta a la suscripción de los miembros de la AEPDIRI. Unos 350 miembros la suscribieron. Su texto y los firmantes pueden verse en la web http://www.aepdiri. org/index.php/actividades-aepdiri/propuestas-de-los-miembros; también en https://web6341.wixsite.com/ independencia-cat. El referéndum ilegal tuvo lugar el 1 de octubre de 2017.

El Tribunal Constitucional en pleno, por unanimidad, en la Sentencia 114/2017, de 17 de octubre, declaró la nulidad de la Ley del Parlamento de Cataluña 19/2017, de 6 de septiembre, denominada «del referéndum de autodeterminación», BOE núm. 256, de 24 de octubre de 2017 (accesible en http:// hi.tribunalconstitucional.es/docs/BOE/BOE-A-2017-12206.pdf). El Tribunal Constitucional ofrece una traducción no oficial de los fundamentos jurídicos y del fallo de esta sentencia, accesible en inglés en https://www.tribunalconstitucional.es/NotasDePrensaDocumentos/NP_2017_074/JUDGMENT\%2020174334STC_EN.pdf y en francés en https://www.tribunalconstitucional.es/NotasDePrensaDocumentos/ NP_2017_074/JUGEMENT\%202017-4334STC_FR.pdf. La Oficina de Prensa del Tribunal también publicó en inglés y francés un resumen en https://www.tribunalconstitucional.es/NotasDePrensaDocumentos/NP_2017_074/PRESS\%20RELEASE\%2074-2017.pdf y https://www.tribunalconstitucional.es/Notas DePrensaDocumentos/NP_2017_074/NOTE\%20D'INFORMATION\%20N\%C2\%BA\%2074-2017_FR.pdf.

Posteriormente, el Tribunal Constitucional en pleno, por unanimidad, en la Sentencia 124/2017, de 8 de noviembre, declaró la nulidad de la Ley del Parlamento de Cataluña 20/2017, de 8 de septiembre, denominada «de transitoriedad jurídica y fundacional de la República», BOE núm. 278, de 16 de noviembre de 2017 (accesible en http://hj.tribunalconstitucional.es/HJ/docs/BOE/BOE-A-2017-13228.pdf). La traducción no oficial de los fundamentos jurídicos y del fallo que ofrece el Tribunal es accesible en francés en https://www.tribunalconstitucional.es/NotasDePrensaDocumentos/NP_2017_085/20174386STC\%20FR.pdf. La Oficina de Prensa publicó un resumen en inglés (accesible en https://www. tribunalconstitucional.es/NotasDePrensaDocumentos/NP 2017 085/PRESS\%20RELEASE\%20852017.pdf) y francés (accesible en https://www.tribunalconstitucional.es/NotasDePrensaDocumentos/ NP_2017_085/NOTE\%20D\%C2\%B4INFORMATION\%20N\%C2\%BA\%2085-2017_FR.pdf).
} 
1. Según la doctrina de las Naciones Unidas y la jurisprudencia internacional, las normas del Derecho internacional general relativas al derecho de autodeterminación de los pueblos sólo contemplan un derecho a la independencia en el caso de los pueblos de los territorios coloniales o sometidos a subyugación, dominación o explotación extranjeras.

2. A la luz de la práctica internacional, no puede excluirse un derecho de separación del Estado a comunidades territoriales cuya identidad étnica, religiosa, lingüística o cultural es perseguida reiteradamente por las instituciones centrales y sus agentes periféricos, o cuyos miembros son objeto de discriminación grave y sistemática en el ejercicio de sus derechos civiles y políticos, de forma que se produzcan violaciones generalizadas de los derechos humanos fundamentales de los individuos y de los pueblos.

3. Nada en los Pactos Internacionales de 1966, en ningún otro tratado sobre derechos humanos, ni en la jurisprudencia internacional apunta a la consagración de un derecho de las comunidades territoriales infraestatales a pronunciarse sobre la independencia y separación del Estado.

4. Las normas generales del Derecho internacional no prohíben que los Estados soberanos, atendiendo al principio de autoorganización, dispongan en sus propios ordenamientos jurídicos supuestos y procedimientos de separación de sus comunidades territoriales. La inmensa mayoría, lejos de hacerlo, proclaman la unidad e integridad territorial como principios básicos de su orden constitucional.

5. La Unión Europea respeta y protege la identidad nacional y la estructura constitucional y de autogobierno de sus Estados. Además, el Derecho de la Unión exige de estos que respeten y hagan respetar el Estado de Derecho, de modo que todos los poderes públicos se sometan a la Constitución, a las leyes y a su aplicación por los tribunales.

6. Como Cataluña no es una entidad que disfrute de un derecho de separación del Estado reconocido por el Derecho internacional, el derecho de libre determinación no puede constituir el fundamento jurídico para consultar a los ciudadanos sobre su independencia, como pretende el referéndum previsto en la Ley 19/2017 del Parlament, actualmente suspendida por el Tribunal Constitucional.

19 de septiembre de 2017 


\section{STATEMENT ON THE LACK OF FOUNDATION IN INTERNATIONAL LAW OF THE INDEPENDENCE REFERENDUM IN CATALONIA ${ }^{2}$}

In view of the errors committed in invoking International Law to substantiate the referendum on the self-determination of Catalonia, the undersigned members of the Asociación Española de Profesores de Derecho Internacional $y$ Relaciones Internacionales («Spanish Association of Professors of International Law and International Relations», or AEPDIRI) deem it our civic duty to issue the following statement on the subject:

1. As per United Nations doctrine and international case-law, international law on the self-determination of peoples provides for a right to pursue independence solely in cases in which populations are under colonial rule or are subject to foreign domination, subjugation or exploitation.

2. In light of international practice, a right of territorial communities to seek separation from a State may not be denied where central institutions

2 Professors Paz Andrés Sáenz de Santa María (University of Oviedo), Gregorio Garzón Clariana (Autonomous University of Barcelona), Araceli Mangas Martín (Complutense University of Madrid), Xavier Pons Rafols (University of Barcelona), Antonio Remiro Brotóns (Autonomous University of Madrid), Alejandro del Valle Gálvez (University of Cádiz) and Rafael Arenas García (Autonomous University of Barcelona), members of the Spanish Association of Professors of International Law and International Relations (AEPDIRI in Spanish acronym), elaborated on September 19, 2017 this «Statement on the lack of foundation in international law of the referendum of independence in Catalonia», which was open to the subscription of the members of the AEPDIRI. Some 350 members signed it. The text of the Statement and the signatories can be accessed at http://www.aepdiri.org/index.php/actividadesaepdiri/propuestas-de-los-members; also at https://web6341.wixsite.com/independencia-cat. The illegal referendum took place on October 1, 2017.

The Constitutional Court of Spain in plenary session, unanimously, in judgment 114/2017, of October 17, 2017, declared the nullity of the Law of the Parliament of Catalonia 19/2017, of September 6, called «of the referendum of self-determination», BOE no. 256 of October 24, 2017 (accessible in Spanish at http://hj.tribunalconstitucional.es/docs/BOE/BOE-A-2017-12206.pdf). The Constitutional Court offers an unofficial translation of the legal grounds and ruling of this judgment, accessible in English at https://www.tribunalconstitucional.es/NotasDePrensaDocumentos/NP_2017_074/JUDGMENT\%20 2017-4334STC_EN.pdf and in French at https://www.tribunalconstitucional.es/NotasDePrensaDocumentos/NP_2017_074/JUGEMENT\%202017-4334STC_FR.pdf. The Court's Press Office also issued a press release No. 74/2017 in English and French, accessible at https://www.tribunalconstitucional. es/NotasDePrensaDocumentos/NP_2017_074/PRESS\%20RELEASE\%2074-2017.pdf and https://www. tribunalconstitucional.es/NotasDePrensaDocumentos/NP_2017_074/NOTE\%20D'INFORMATION\%20 N\%C2\%BA\%2074-2017_FR.pdf.

Subsequently, the Constitutional Court in plenary session, unanimously, in the judgment 124/2017, of November 8, 2017, declared the nullity of the Law of the Parliament of Catalonia 20/2017, of September 8, called «legal transience and foundation of the Republic», BOE no. 278 of November 16, 2017 (accessible in Spanish at http://hj.tribunalconstitucional.es/HJ/docs/BOE/BOE-A-2017-13228. $p d f$ ). The unofficial translation of the legal grounds and ruling of this judgment is accessible in French at https://www.tribunalconstitucional.es/NotasDePrensaDocumentos/NP_2017_085/20174386STC\%20FR.pdf. The press release 85/2017 in English and French is accessible at https://www. tribunalconstitucional.es/NotasDePrensaDocumentos/NP_2017_085/PRESS\%20RELEASE\%2085-2017. pdf and https://www.tribunalconstitucional.es/NotasDePrensaDocumentos/NP_2017_085/NOTE\%20 D\%C2\%B4INFORMATION\%20N\%C2\%BA\%2085-2017_FR.pdf. 
and other agents repeatedly persecute community members due to their ethnic, religious, linguistic or cultural identity or systematically subject individuals and peoples to serious discrimination in the exercise of their civil and political rights, resulting in widespread violations of basic human rights of individuals or peoples.

3. No provision whatsoever in the International Covenants of 1966, in any other human rights treaty or in international case-law, enshrines any right of regional or territorial communities to issue declarations regarding their independence and secession from the State.

4. In keeping with the principle of self-governance, the general rules of international law do not prevent sovereign states from establishing their own legal framework and procedures for the separation of their territorial communities. Nonetheless, the vast majority of States proclaim their unity and territorial integrity to be basic pillars of their constitutional order.

5. The European Union respects and protects the national identity as well as the constitutional and governing frameworks of its Member States. Moreover, EU law requires the latter to respect and enforce the rule of law to ensure that all public authorities adhere to the Constitution, the law, and their application by the courts.

6. As Catalonia does not represent an entity which would be entitled to the right of separation from the State recognized in international law, the right to self-determination cannot serve as the legal basis for consulting its citizens on the subject of its independence, as claimed for the referendum foreseen in Catalan Parliamentary Act 19/2017, currently suspended by the Spanish Constitutional Court.

September 19, 2017 